\title{
Osedax mucofloris (Polychaeta, Siboglinidae), a bone-eating marine worm
}

\section{new to Norway}

\author{
Christoffer Schander, Hans Tore Rapp and Thomas G. Dahlgren
}

Schander C, Rapp HT and Dahlgren TG. 2010. Osedax mucifloris (Polychaeta, Siboglinidae), a boneeating marine worm new to Norway. Fauna norvegica 30: 5-8.

The bone-eating siboglinid polychaete Osedax mucofloris Glover, Källström, Smith \& Dahlgren, 2005 is reported from Norwegian waters for the first time. Dense growth was found on bovine bones deposited at 118 meters depth off western Norway. Dwarf males were observed for the first time. The two specimens sequenced were identical to haplotypes previously found at a Swedish whale fall. The possibility of finding additional species of Osedax is discussed.

Keywords: Whale fall, Siboglinidae, Annelida, fjord, Scandinavia, deep sea, reducing habitats

doi: 10.5324/fn.v30i0.632. Recieved: 2010-04-18. Accepted: 2010-08-18. Published online: 2010-12-21.

Christoffer Schander, University of Bergen, Department of Biology, P.O. Box 7800, 5020 Bergen, Norway, University of Bergen, Centre for Geobiology, Allégaten 36, 5020 Bergen, Norway and Uni Miljø, P.O. Box 7810, 5020 Bergen, Norway. (Current address: 101 Life Sciences Building, Department of Biological Sciences, Auburn University, Auburn Alabama 36849 USA). Hans Tore Rapp, University of Bergen, Department of Biology, P.O. Box 7800, 5020 Bergen, Norway and University of Bergen, Centre for Geobiology, Allégaten 36, 5020 Bergen, Norway.

Thomas G. Dahlgren, Uni Miljø, P.O. Box 7810, 5020 Bergen, Norway and University of Gothenburg, Department of Zoology, Box 463, 40530 Göteborg, Sweden.

Corresponding author: Christoffer Schander

E-mail: Christoffer.Schander@bio.uib.no

\section{INTRODUCTION}

Specialized marine fauna associated with chemoautotrophic ecosystems have been intensely studied in recent years. These ecosystems include hydrothermal vents (e.g. Van Dover, 2000; Desbruyères et al. 2006; Schander et al. 2010 and references therein), hydrocarbon seeps (e.g. Levin 2005; Cordes et al. 2009; Van Gaever et al. 2009), wood falls (e.g. Pailleret et al. 2009; Bernardino et al. 2010) and whale falls (e.g. Smith \& Baco 2003; Dahlgren et al. 2004; Wiklund et al. 2009). A range of novel species as well as unusual microbial and macrofaunal interactions have been discovered.

The genus Osedax was first described from two species found at a naturally-occurring whale-carcass (or 'whale-fall') off California (Rouse et al. 2004). Other species have since been described from Sweden (Glover et al. 2005) and Japan (Fujikura et al 2006). A fifth species was described by Rouse et al.
(2008) and 12 additional "species" were listed, but not formally described by Vrijenhoek et al. (2009). One putative species of a bone eating siboglinid worm has also been named based on trace fossils from remains of a Lower Pliocene (5.3-3.6 Ma) baleen whale (Mysticeti) from Alméría, Spain under the name Trypanites ionasi (Muñiz et al. 2010). The evidence presented in this paper is however not conclusive that this trace is Osedax, or even any kind of bone-eating macrofauna. More likely traces of Osedax were reported by Kiel at al. (2010) from two early Oligocene whale-falls.

Since it has been shown that Osedax grows on any large mammal bone (e.g. Jones et al. 2008, but see Glover et al. 2008), we placed a number of bovine bones in a fjord south of Bergen, Norway, to study possible colonization. Here we report on the results of this study. 


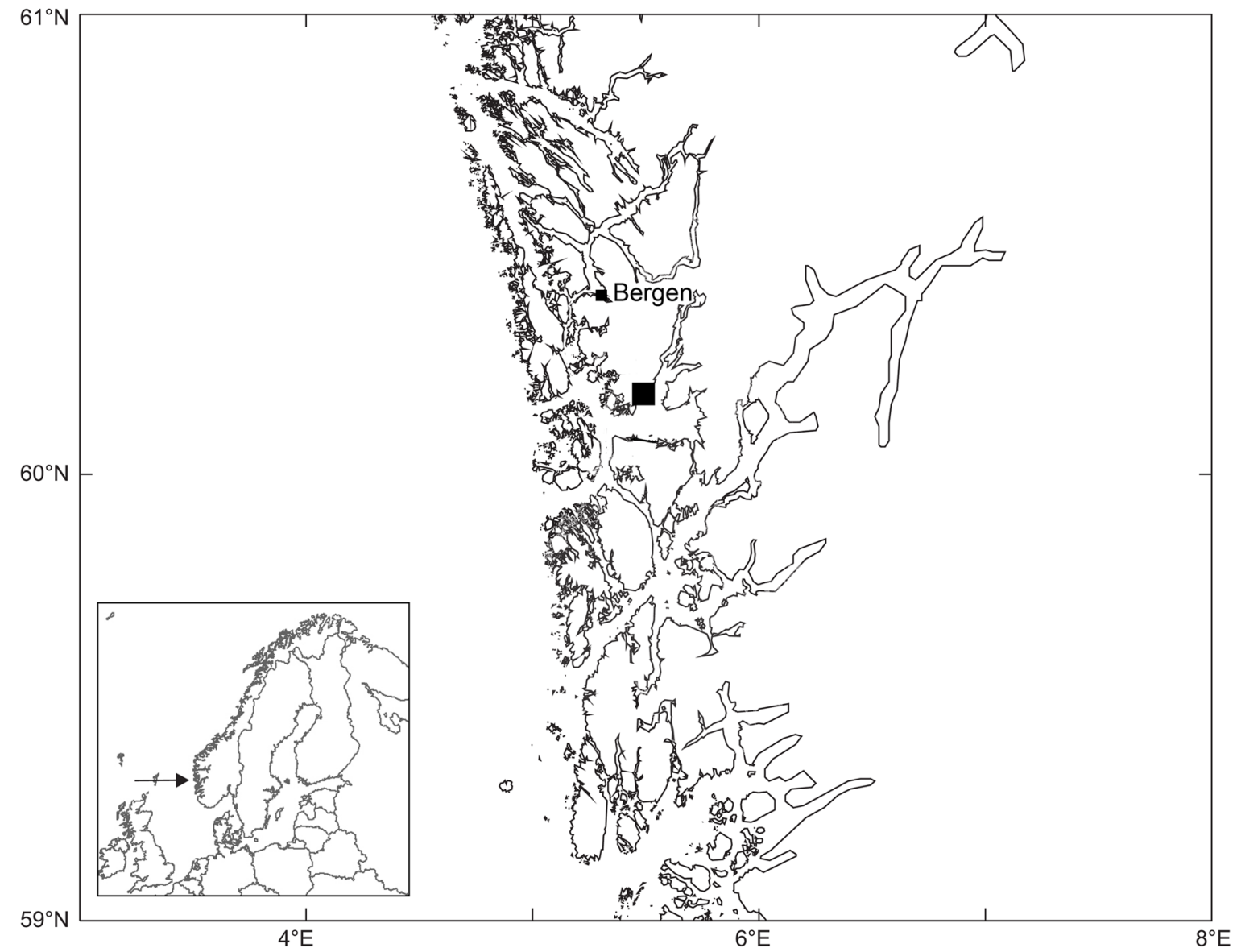

Figure I. Map of the locality (square) of the artificial whale falls in Bjørnafjord, Hordaland, Norway (Background map provided by Institute of Marine Research, Norway).

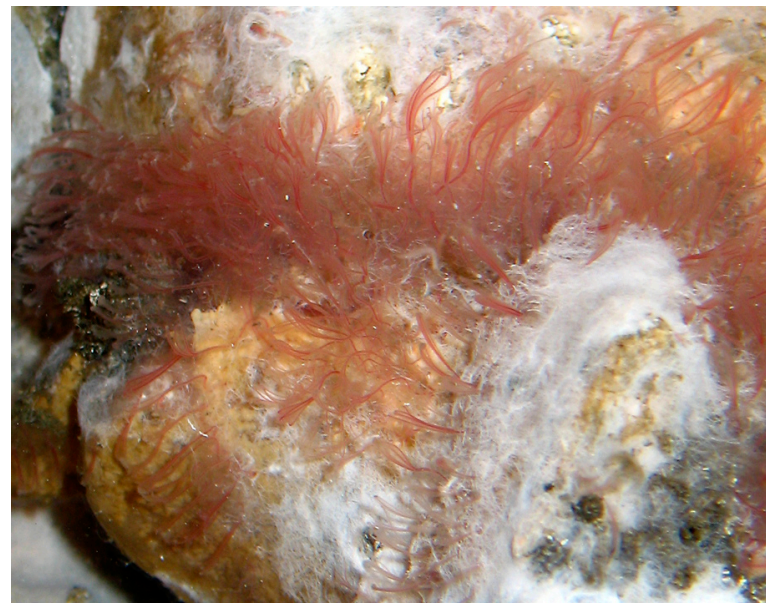

Figure 2. Dense growth of Osedax mucofloris on a bovine bone in a laboratory aquarium. White growth is Beggiatoa-like bacteria. Photo: David Osca Ferriol.

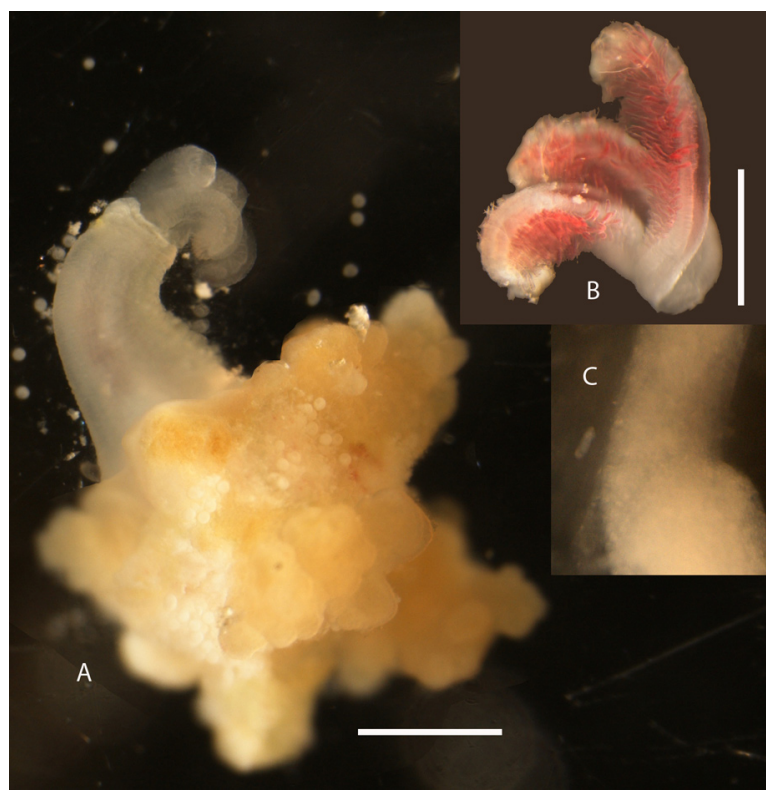

Figure 3. Osedax mucofloris from Bjørnafjord, Western Norway. A. Live, dissected female surrounded by eggs. Scale bar $1 \mathrm{~mm}$. B. Detail of palps. Scale bar $250 \mu \mathrm{m}$. C. Dwarf male, alongside oviduct. Photo: Schander \& Dahlgren. 


\section{MATERIAL AND METHODS}

Twenty bovine bones (bought in a pet shop) were sunk in Bjørnafjord south of Bergen at $118 \mathrm{~m}$ depth at position $60^{\circ} 11,057598 \mathrm{~N}, 05^{\circ} 30,527768 \mathrm{E}$ (Figure 1) in April 2009 during a cruise with R/V Haakon Mosby. The hydrography of the area is described in Hosia \& Båmstedt (2007). The bones were $30-35 \mathrm{~cm}$ long and arranged on a $2 \times 2 \mathrm{~m}$ PVC frame. Some of the bones were recovered in February 2010 using the ROV Aglantha. The recovered bones were inspected under a stereo microscope on board, and dense growth of Osedax could be observed. Some of the specimens were dissected out and placed in Eppendorph tubes with $96 \%$ ethanol for molecular analysis. The specimens were extracted and sequenced using the primers and protocol $\mathrm{g}$ iven in Glover et al. (2005). The obtained sequences were checked against available data in GenBank using BLAST. Two COI sequences have been deposited in GenBank (Accession numbers HM045512 \& HM045513).

Two bones were taken to the laboratory and Osedax have been kept alive in an aquarium with running seawater for several months (Figure 2).

\section{RESULTS AND DISCUSSION}

Both morphology and DNA barcoding (e.g. Schander \& Willassen 2005) identified the species as Osedax mucofloris Glover, Källström, Smith \& Dahlgren, 2005 (Figures 2 \& 3). BLAST searches resulted in $100 \%$ match with GenBank Accession numbers AY827568.1 (Osedax mucofloris haplotype G) and AY827563.1 (Osedax mucofloris haplotype B).

In the original description of Osedax mucofloris it is mentioned that the authors could not find any dwarf males in spite of examining 50 free-dissected specimens. Dwarf males were however present in our specimens, located along the oviduct (Figure 3c).

Norwegian waters harbor populations of a number of large bodied whale species including blue whale (Balaenoptera musculus), fin whale (Balaenoptera physalus), sei whale (Balaenoptera borealis), minke whale (Balaenoptera acutorostrata), sperm whale (Physeter macrocephalus), pilot whale (Globicephala melas), and northern bottlenose whale (Hyperodon ampullatus). Carcasses of all these species are the probable sources of natural habitats for Osedax mucofloris in Norway. The type locality of $O$. mucofloris is an experimentally implanted minke whale carcass at $125 \mathrm{~m}$ depth in a Swedish fjord (Glover et al. 2005). Additional Swedish populations have been found at a pilot whale carcass at $30 \mathrm{~m}$ depth (Dahlgren et al. 2006) and at four sperm whale vertebrae collected in a shrimp trawl from a depth of 60-90 meters (Dahlgren, unpublished).

This study shows that Osedax mucofloris is widespread in Scandinavian waters. In light of the many Osedax species found in the Pacific Ocean, it can be expected that a high diversity of bone eating worms will be discovered also in the Atlantic. The distribution patterns are likely dependent on depth (Braby et al. 2007), and we have therefore recently deployed new bone experiments at 600 meters. More extensive genetic comparisons between the Swedish and Norwegian material is currently carried out.

\section{ACKNOWLEDGEMENTS}

We would like the crew of R/V Haakon Mosby for excellent working conditions on board, and the pilots of ROV Aglantha for skillfully recovering our samples. Solveig Thorkildsen is thanked for help in the laboratory. This is contribution number 70 from AU Marine Biology Program.

\section{REFERENCES}

Bernardino AF, Smith CR, Baco A, Altamira I, Sumida PYG. 2010. Macrofaunal sucession in sediments around kelp and wood falls in the deep NE pacific community overlap with other reducing habitats. Deep-Sea Research I. doi:10.1016/j.dsr.2010.03.004

Braby CE, Rouse GW, Johnson SB, Jones WJ, Vrijenhoek R. C. 2007. Bathymetric and temporal variation among Osedax boneworms and associated megafauna on whale-falls in Monteray Bay, California. Deep-Sea Research I 54: 1773-1791.

Cordes EE, Bergquist DC, Fisher CR. 2009. Macro ecology of Gulf of Mexico cold seeps. Annual Review of Marine Science 1: 143-168.

Dahlgren TG, Glover AG, Baco A, Smith C. R. 2004. Fauna of whale falls: systematics and ecology of a new polychaete (Annelida: Chrysopetalidae) from the deep Pacific Ocean. Deep-Sea Research I 51: 1873-1887.

Dahlgren TG, Wiklund H, Källström B, Lundälv T, Smith CR, Glover AG. 2006. A shallow-water whale-fall experiment in the north Atlantic. Cahiers De Biologie Marine 47: 385-389.

Desbruyères D, Segonzac M, Bright M. (Eds.) 2006. Handbook of deep-sea hydrothermal vent fauna. Densia 18: 1-544.

Fujikura K, Fujuwara Y, Kawato M. 2006. A new species of Osedax (Annelida: Siboglinidae) associated with whale carcasses off Kyushu, Japan. Zoological Science 23: 733-740.

Glover AG, Källström B, Smith CR, Dahlgren TG. 2005. Worldwide whale worms? A new species of Osedax from the shallow north Atlantic. Proceedings of the Royal Society B. 272: 25872592.

Glover AG, Kemp KM, Smith CR., Dahlgren TG. 2008. On the role of bone-eating worms in the degradation of marine vertebrate remains. Proceedings of the Royal Society B-Biological Sciences, 275: 1959-1961.

Hosia A, Båmstedt U. 2007. Seasonal changes in the gelatinous zooplankton community and hydromedusa abundances in Korsfjord and Fanafjord, western Norway. Marine Ecology Progress Series 351: 113-127.

Jones WJ, Johnson SB, Rouse GW, Vrijenhoek RC. 2008. Marine worms (genus Osedax) colonize cow bones. Proceedings of the Royal Society B. 27: 387-391. 
Kiel S, Goedert JL, Kahl W-A, Rouse GW. 2010. Fossil traces of the bone-eating worm Osedax in early Oligocene whale bones. Proceedings of the National Academy of Sciences, Early Edition. www.pnas.org/cgi/doi/10.1073/pnas.1002014107.

Levin L. 2005. Ecology of cold seep sediments: interactions of fauna with flow chemistry and microbes. Oceanography and Marine Biology: An Annual Review 43: 1-46.

Muniz F, De Gibert JM, Esperante R. 2010. First trace-fossil evidence of bone-eating worms in whale carcasses. Palaios 25: 269-273.

Pailleret M, Haga T, Petit P, Privé-Gill C, Saedlou N, Gaill F, Zbinden M. 2007. Sunken wood from Vanuatu Islands: identification of wood substrates and preliminary description of associated fauna. Marine Ecology 28: 233-241.

Rouse G, Goffredi SK, Vrijenhoek RC. 2004. Osedax: Bone-eating marine worms with dwarf males. Nature 305: 668-671.

Rouse G, Worsaae K, Johnson SB, Jones WJ, Vrijenhoek RC. 2008. Acquisition of dwarf male "harems" by recently settled females of Osedax roseus n. sp. (Siboglinidae; Annelida). Biological Bulletin 214: 67-82.

Schander C, Rapp HT, Kongsrud JA, Bakken T, Berge J, Cochrane S, Oug E, Byrkjedal I, Todt C, Cedhagen T, Fosshagen A, Gebruk A, Larsen K, Levin L, Obst M, Pleijel F, Stöhr S, Warén A, Mikkelsen NT, Hadler-Jacobsen S, Keuning R, Heggøy Petersen K, Thorseth IH, Pedersen RB. 2010. The fauna of hydrothermal vents on the Mohn Ridge (North Atlantic). Marine Biology Research 6: 155-171.

Schander C, Willassen E. 2005. What can biological barcoding do for marine biology? Marine Biology Research 1: 79-83.

Smith CR, Baco AR. 2003. Ecology of whale falls at the deep-sea floor. Oceanography and Marine Biology: an Annual Review 41: 311-354.

Van Dover C. 2000. The ecology of Deep-Sea hydrothermal vents. Princeton University Press, Princeton 424 pp.

Van Gaever S, Olu K, Derycke S, Vanreusel A. 2009. Metazoan meiofaunal communities at cold seeps along the Norwegian margin: influence of habitat heterogeneity and evidence for connection with shallow-water habitats. Deep-Sea Research I 56: $772-785$.

Vrijenhoek RC, Johnson SB., Rouse GW. 2009. A remarkable diversity of bone-eating worms (Osedax; Siboglinidae; Annelida). BMC Biology 7: 74. Doi:10.1186/1741-7007-7-74.

Wiklund H, Glover AG, Dahlgren TG. 2009. Three new species of Ophryotrocha (Annelida: Dorvillidae) from a whale-fall in the North-East Atlantic. Zootaxa 2228: 43-56 